\title{
TAXONOMIC STATUS OF TANTILLA EQUATORIANA WILSON AND MENA 1980 (SERPENTES: COLUBRIDAE)
}

\author{
Eli Greenbaum,* John L. Carr, and Ana Almendáriz
}

\author{
Division of Herpetology, Natural History Museum and Biodiversity Research Center, and Department of Ecology and \\ Evolutionary Biology, 1345 Jayhawk Boulevard, University of Kansas, Lawrence, KS 66045-7561 (EG) \\ Department of Biology, University of Louisiana at Monroe, Monroe, LA 71209-0520 (JLC) \\ Departamento de Ciencias Biológicas, Escuela Politécnica Nacional, Apartado 17-01-2759, Quito, Ecuador (AA) \\ *Correspondent: elig@ku.edu
}

\begin{abstract}
The colubrid snake Tantilla equatoriana was described from 2 male specimens on the basis of several characters of color pattern and relatively high number of subcaudals. We examined the types and 3 additional specimens of T. equatoriana to assess whether the characters used to diagnose this taxon are unique or overlap with those of the highly variable, sympatric species $T$. melanocephala. Based on these data and a Principal Components Analysis of morphometric variation of T. equatoriana and T. melanocephala, we treat T. equatoriana as a junior synonym of T. melanocephala.
\end{abstract}

RESUMEN-La descripción original del colúbrido Tantilla equatoriana fue basada en dos especímenes machos y hace énfasis en los patrones de coloración y el número relativamente alto de escamas subcaudales. Examinamos los especímenes tipo y tres especímenes adicionales de T. equatoriana para determinar si las características utilizadas para diagnosticar a esta especie son únicas o si se sobreponen con las de T. melanocephala, una especie simpátrica muy variable. Basados en los resultados obtenidos y en un análisis de componentes principales de la variación morfométrica de T. equatoriana y T. melanocephala, consideramos que T. equatoriana es un sinónimo secundario de T. melanocephala.

As currently understood, the colubrid genus Tantilla contains 58 species of snakes in the New World (Wilson, 1999; Canseco-Márquez et al., 2002; Savage, 2002; Sawaya and Sazima, 2003; Stafford, 2004). Savage (2002) noted that one of these taxa, T. ruficeps, might intergrade with $T$. melanocephala in Panama and western Colombia. The T. melanocephala Group is the second largest species group in the genus and includes T. andinista, T. capistrata, $T$. equatoriana, T. insulamontana, T. lempira, T. melanocephala, and T. miyatai (Wilson, 1999). Tantilla melanocephala (Linnaeus, 1758) has the broadest distribution of any species of Tantilla, extending from central Panama to Argentina in a variety of humid and subhumid habitats from near sea level to over 2,700 m elevation (Wilson and Mena, 1980; Savage, 2002). This species is characterized by extensive geographic variation in color pattern, ventral and subcaudal counts, and habitats occupied (Wilson and Mena, 1980). This color variation prompt- ed Wilson and Mena (1980) to recognize 6 pattern types (A through F) of T. melanocephala. In the same paper, these authors described $T$. equatoriana from the Pacific lowlands of Ecuador; they believed T. equatoriana to be distinct from, but closely related to, T. melanocephala.

Tantilla equatoriana was described from 2 male specimens of undetermined maturity from San Lorenzo, Esmeraldas Province, Ecuador (Wilson and Mena, 1980). This taxon was distinguished from all congeners by several characters: 1) a dark head cap grading into a dark nape band with 2 pale spots that cover the posterior part of the parietals, the posterior part of the posterior temporals, and associated postparietal scales; 2) a pale preocular "spot" that contacts the preocular scale and eye; 3) a postocular "spot" that contacts the lateral gulars without interruption by a lateral extension of the head cap; 4) the absence of a pale neck band posterior to the dark nape band; 5) a tan background color with 9 dark 
brown stripes (in the middle of Scale Row 1, extending from the upper half of Row 2 to the lower half of Row 3, the top of Row 4 to the bottom of Row 5, the middle of Row 6 and the middle of the vertebral Scale Row 8); and 6) a greater number of subcaudals (77 to 79) in comparison with other members of the T. melanocephala Group (Wilson and Mena, 1980; Wilson, 1988).

In 1988 and 1991, 2 additional specimens of Tantilla equatoriana were collected in Esmeraldas Province, Ecuador (Parker and Carr, 1992; see Appendix I). With the availability of the additional specimens, we began to evaluate the characters proposed by Wilson and Mena (1980) to distinguish T. equatoriana from its congeners. In addition to the holotype, paratype, and 2 recently collected specimens, an additional specimen (USNM 198728) from Pichincha Province, Ecuador, previously identified as T. melanocephala (Wilson and Mena, 1980), was found to fit the description of $T$. equatoriana. Herein, we compare the color pattern and morphology of T. equatoriana and $T$. melanocephala, and evaluate the validity of the former taxon.

Methods-The holotype and 4 additional specimens of T. equatoriana were compared with 42 specimens of T. melanocephala pattern types $\mathrm{E}$ and $\mathrm{F}$ (sensu Wilson and Mena, 1980) from localities in Colombia and Ecuador west of the Andes and from Panama (Appendix I). Specimens were identified as $T$. equatoriana only if they possessed all 5 of the diagnostic color pattern characteristics described by Wilson and Mena (1980); subcaudal counts were not considered because there were only 2 specimens of T. equatoriana in the original description and both were males. The ranges of pattern types A through $\mathrm{D}$ of $T$. melanocephala do not overlap that of T. equatoriana (Wilson and Mena, 1980) and were not included in the present study. To assess the sexual maturity of the type series (both approximately the same size), the paratype was dissected to examine the gonads.

Measurements for multivariate analysis were based on previous studies that examined interspecific and intraspecific variation in snakes (Thorpe, 1985; Burbrink, 2001). Snout-vent length (SVL) and tail length (TL) measurements were taken with a metric ruler to the nearest $1 \mathrm{~mm}$; other measurements were taken with dial calipers under a stereomicroscope to the nearest $0.1 \mathrm{~mm}$. Ventral scale counts were based on the method of Dowling (1951). Museum acronyms are listed in Leviton et al. (1985).
The following data were recorded for every examined specimen: 1) sex; 2) number of ventrals (Ven); 3) number of subcaudals (Sub); 4) SVL; 5) TL; 6) number of supralabials; 7) number of supralabials entering orbit; 8) number of infralabials; 9) largest infralabial; 10) number of infralabials in contact with the anterior chin shields; 11) number of loreals; 12) number of preoculars; 13) number of postoculars; 14) number of anterior temporals; 15) number of posterior temporals; (16) divided or entire anal plate (cloacal scute); 17) scale rows at neck; 18) scale rows at midbody; 19) scale rows one headlength anterior to the vent; 20) number of dark longitudinal stripes on dorsum (DLS); 21) head depth at center of frontal (HedDep); 22) distance from most anterior point of head to anterior border of 1 st ventral (Ant1st); 23) distance between nostrils (NosDis); 24) right parietal length (RParL); 25) right parietal width (RParW); 26) frontal length (FroL); 27) frontal width (FroW); 28) right anterior temporal length (RATL); 29) right anterior temporal width (RATW); 30) right posterior temporal length (RPTL); 31) right posterior temporal width (RPTW); 32) right most-posterior supralabial length (RSupL); 33) right most-posterior supralabial width (RSupW); 34) longitudinal length of first ventral (1stVen); 35) interorbital distance between the lateral margins of the eye scales (Inter); 36) head width at jaw articulation (HW); 37) body width at midbody (Midbod); 38) body width at vent (Vent); 39) eyenostril distance on right side of head (EyeNR); and 40) right eye diameter (EyeDR).

Meristic data (characters 2, 3, and 6 through 20) and 2 measurements ( 4 and 5 ) were taken to illustrate general trends in the geographic variation of T. melanocephala as compared to that in T. equatoriana. Because of damage to some specimens, it was not possible to include meristic or tail length data in our multivariate analysis, which required data from every specimen to be included. We performed a Principal Components Analysis (PCA) on the included data to assess overall morphological variation in size and shape between the 2 putative taxa without making a priori assumptions about groupings. To avoid violations of non-independent data in the PCA, measurements were taken from the right side of the body only (Manly, 1994). Mensural data were log-transformed (Burbrink, 2001), and the PCA was performed on the correlation matrix in Minitab version 13 .

RESults-Head Cap-All examined specimens of T. melanocephala possessed a dark head cap that graded into a dark nape band with 2 pale spots; all but 3 specimens (MCZ 147302, 166542; USNM 285502; all from Pichincha Province, Ecuador) possessed spots on the pa- 
rietals and temporals. Thus, the head cap and posterior spot patterns described by Wilson and Mena (1980) for T. equatoriana do not diagnose the taxon from $T$. melanocephala.

Preocular Spot-This character refers to a circular area (spot) on the preocular scale that is not covered in brown pigment, thus allowing the cream-colored (pale) background pigment of the scale to show through. However, the stipulation by Wilson and Mena (1980) that the preocular spot contacts the eye is not clear from the description. Wilson and Mena (1980: fig. 9) illustrated the holotype of T. equatoriana with the spot separated from the eye by a thin, dark-brown line, but no such line was explained in the description. Although none of the specimens of $T$. melanocephala possessed a spot that entered the preocular scale to touch the eye, some specimens of T. equatoriana displayed variation in this character. One specimen of T. equatoriana (EPN 2552) had almost no cream-colored areas entering the preocular on either side, and contact with the eye was absent. Another specimen (EPN 8654) had a cream-colored spot on the left preocular, but the right preocular barely contained any areas that were free of brown pigmentation. We argue that this is a poor character for species delimitation because of the equivocal delimitation of the character in the original species description of $T$. equatoriana, and because of the variation noted in the recently collected EPN specimens of T. equatoriana.

Postocular Spot-As with the preocular spot above, this character refers to a roughly circular area (spot) that lacks brown pigment and thus seems to be pale in coloration. The postocular pale area contacted the lateral gulars without interruption from the lateral extension of the head cap in several specimens of $T$. melanocephala from the Ecuadorian provinces of Cotopaxi (USNM 198730), Esmeraldas (QCAZ 2235), Loja (USNM 198736), and Pichincha (MCZ 164419; QCAZ 393, 1569; USNM 198729-33, 287934, 287936-37). The postocular pale spot was absent in all other specimens of T. melanocephala. Thus, the postocular-spot character described by Wilson and Mena (1980) for T. equatoriana does not diagnose the taxon from T. melanocephala.

Neck Band-Several specimens of T. melanocephala from Valle del Cauca Department, Colombia (AMNH 4480) and Ecuadorian prov- inces of Cotopaxi (QCAZ 206), Loja (USNM 198736), and Pichincha (MCZ 164503, 166542; QCAZ 393, 1651; USNM 198731, 198733, 287937) lacked the pale band posterior to the dark nape band. Two specimens from the Ecuadorian provinces of Cotopaxi (USNM 198730) and Pichincha (USNM 198729) had 2 pale spots posterior to the dark nape band instead of a complete band. The remaining specimens of T. melanocephala possessed a pale band posterior to the dark nape band. Thus, the neck-band character described by Wilson and Mena (1980) for T. equatoriana does not diagnose the taxon from T. melanocephala.

Stripe Pattern-Several specimens of T. melanocephala possessed a pattern of dorsal stripes nearly identical to that in specimens referred to $T$. equatoriana, including a specimen of the former species from Nariño Department, Colombia (AMNH 20400), only $75 \mathrm{~km} \mathrm{~N}$ of the type locality of T. equatoriana (Fig. 1). A similar pattern was present in 2 specimens from Santo Domingo de los Colorados, Pichincha Province, Ecuador (MCZ 147302; USNM 285502), the same locality as 1 of the specimens of $T$. equatoriana (USNM 198728). Other T. melanocephala with a stripe pattern similar to T. equatoriana included specimens from localities in Pichincha Province, Ecuador (QCAZ 1283; USNM 198732). One specimen of T. melanocephala from Cotopaxi Province, Ecuador (USNM 198730), differed from the T. equatoriana pattern only by having a stripe between Scale Rows 5 to 6 instead of 4 to 5. Another specimen from Valle del Cauca Department, Colombia (USNM 267258), differed from the T. equatoriana pattern by the absence of the third stripe from the upper portion of Scale Row 4. Numerous additional specimens possessed a pattern of body stripes that differed from T. equatoriana by 1 scale row. Therefore, the stripe pattern described for T. equatoriana by Wilson and Mena (1980) is not diagnostic of the taxon and displays considerable variation within T. melanocephala (Table 1).

Subcaudals_-Wilson and Mena (1980) noted that T. equatoriana could be distinguished from congeners by the relatively high number of subcaudals (77 to 79 ), as compared to $T$. $m e^{-}$ lanocephala (50 to 72 for Ecuadorian specimens). However, 1 of the newly obtained male specimens of T. equatoriana (EPN 8654) had 69 subcaudals (tail is complete), which fell within 
A
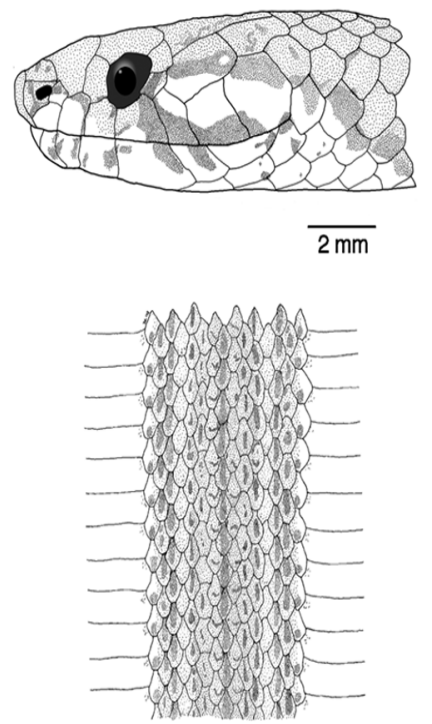

B
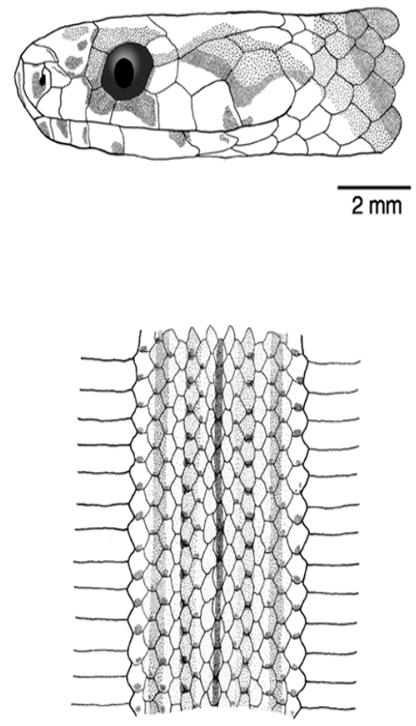

C

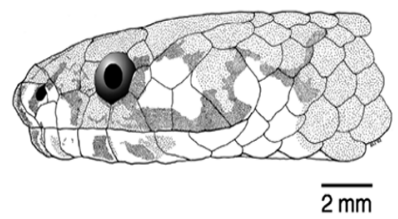

FIG. 1-Lateral views of the head and dorsal views of the color pattern in A) Tantilla equatoriana (EPN 2552); B) T. melanocephala (AMNH 20400) Pattern E; and C) T. melanocephala (KU 202954) Pattern F.

the range of subcaudal counts of $T$. melanocephala from Panama (FMNH 83554, 170141; MCZ 23870, 23872; USNM 140702), Colombia (MVZ 68711, USNM 267258), and Ecuador (Wilson and Mena, 1980:13). Thus, the relatively higher number of subcaudals is not a diagnostic character of T. equatoriana. Moreover, all subcaudal counts noted for $T$. equatoriana were from males; the only known female (EPN 2552) had an incomplete tail. The paratype of T. equatoriana was an immature male based on the rudimentary development of the testes and urogenital ducts. Because males of T. melanocephala tend to have a higher number of subcaudals than females (Wilson and Mena, 1980), the previously observed difference in subcaudals between $T$. melanocephala and $T$. equatoriana almost assuredly is an artifact of sexual dimorphism and sample size.

Ventrals-Number of ventrals ranged from 144 to 150 in specimens of T. equatoriana, and from 133 to 167 in specimens of T. melanocephala (Table 1). In the provinces of Esmeraldas and Pichincha, where T. equatoriana has been recorded, ventral counts of $T$. melanocephala ranged from 143 to 156 . Thus, the observed variation in number of ventrals in T. equatori- ana is entirely encompassed within that of $T$. melanocephala.

Other Body Scales-With 1 exception, all specimens of $T$. equatoriana and $T$. melanocephala had 7 supralabials, with Supralabials 3 and 4 entering the orbit; 6 infralabials (Infralabial 4 largest); 4 infralabials in contact with the anterior chin shields; no loreal; 1 preocular; 2 postoculars; 1 anterior and 1 posterior temporal; a divided anal plate; and 15 scale rows throughout the body. One specimen of T. melanocephala (USNM 287937) differed from the above characteristics by having 6 supralabials, with Supralabials 3 and 4 entering the orbit, and 14 scale rows 1 head-length anterior to the vent.

Principal Components Analysis-The PCA (Fig. 2; Table 2) did not indicate any differences between the 2 putative species examined. Because loadings for Principal Component (PC) 1 were of the same magnitude and sign, the axis represents overall size; larger snakes are on the left side of the graph. The eigenvalue for PC1 was 15.581, accounting for $74.2 \%$ of the variation observed among specimens. The eigenvalue for PC2 was 1.147, accounting for $5.5 \%$ of the total variation among specimens. 
TABLE 1-Comparison of snout-vent length (SVL), tail length (TL), numbers of ventral (Ven) and subcaudal (Sub) scales, and dark longitudinal stripes (DLS) of Tantilla equatoriana (eq), and T. melanocephala (me). Data are presented as averages \pm 1 SD, followed by ranges in parentheses. Provinces and departments are listed in order from north to south

\begin{tabular}{|c|c|c|c|c|c|c|c|c|c|c|}
\hline Species & Country & $\begin{array}{c}\text { Province/ } \\
\text { Department }\end{array}$ & $\begin{array}{l}\text { SVL } \\
(\mathrm{mm})\end{array}$ & $\begin{array}{c}\mathrm{TL} \\
(\mathrm{mm})\end{array}$ & $\begin{array}{c}\text { Ven } \\
\text { (males) }\end{array}$ & $\begin{array}{c}\text { Ven } \\
\text { (females) }\end{array}$ & $\begin{array}{c}\text { Sub } \\
\text { (males) }\end{array}$ & $\begin{array}{c}\text { Sub } \\
\text { (females) }\end{array}$ & DLS & $n$ \\
\hline me & Panama & Panamá & $\begin{array}{c}209.2 \pm 47.23 \\
\quad(150-276)\end{array}$ & $\begin{array}{c}71.6 \pm 10.60 \\
(56-84)\end{array}$ & $\begin{array}{c}145.5 \pm 0.71 \\
(145-146)\end{array}$ & $\begin{array}{c}149.67 \pm 4.51 \\
(145-154)\end{array}$ & $\begin{array}{c}77.5 \pm 2.12 \\
(76-79)\end{array}$ & $\begin{array}{c}70.33 \pm 4.16 \\
(67-75)\end{array}$ & $\begin{array}{c}6.3 \pm 1.03 \\
(5-7)\end{array}$ & 6 \\
\hline me & Panama & Darién & 270 & 76 & 145 & - & 77 & - & 7 & 1 \\
\hline me & Colombia & Chocó & 262 & - & 159 & - & - & - & 7 & 1 \\
\hline me & Colombia & Valle del Cauca & $\begin{array}{c}278.0 \pm 26.15 \\
\quad(260-308)\end{array}$ & $\begin{array}{c}110.5 \pm 0.71 \\
\quad(110-111)\end{array}$ & $\begin{array}{c}150.5 \pm 12.02 \\
(142-159)\end{array}$ & - & 80 & 69 & $\begin{array}{c}5.0 \pm 3.46 \\
(3-9)\end{array}$ & 3 \\
\hline me & Colombia & Nariño & $\begin{array}{c}220.0 \pm 28.28 \\
(200-240)\end{array}$ & - & $\begin{array}{c}164.0 \pm 4.24 \\
\quad(161-167)\end{array}$ & - & - & - & $\begin{array}{c}7.0 \pm 2.83 \\
(5-9)\end{array}$ & 2 \\
\hline me & Ecuador & Esmeraldas & 182 & - & - & 143 & - & - & 7 & 1 \\
\hline eq & Ecuador & Esmeraldas & $\begin{array}{c}212.8 \pm 101.01 \\
(152-363)\end{array}$ & $\begin{array}{c}63.3 \pm 7.57 \\
(58-72)\end{array}$ & $\begin{array}{c}145.33 \pm 1.53 \\
\quad(144-147)\end{array}$ & 150 & $\begin{array}{c}75.0 \pm 5.29 \\
(69-79)\end{array}$ & - & $9.0 \pm 0.0$ & 4 \\
\hline eq & Ecuador & Pichincha & 315 & 118 & 146 & - & 72 & - & 9 & 1 \\
\hline me & Ecuador & Pichincha & $\begin{array}{c}240.0 \pm 60.28 \\
\quad(111-323)\end{array}$ & $\begin{array}{c}72.9 \pm 25.66 \\
(27-108)\end{array}$ & $\begin{array}{c}143.69 \pm 5.49 \\
(133-155)\end{array}$ & $\begin{array}{c}148.13 \pm 4.09 \\
(144-156)\end{array}$ & $\begin{array}{c}56.56 \pm 3.47 \\
(52-61)\end{array}$ & $\begin{array}{c}59.6 \pm 4.51 \\
(53-65)\end{array}$ & $\begin{array}{c}7.0 \pm 1.27 \\
(5-9)\end{array}$ & 24 \\
\hline me & Ecuador & Cotopaxi & $\begin{array}{c}250.0 \pm 28.28 \\
(230-270)\end{array}$ & $\begin{array}{c}83.5 \pm 0.71 \\
(83-84)\end{array}$ & $\begin{array}{c}145.0 \pm 1.41 \\
(144-146)\end{array}$ & - & $\begin{array}{c}59.5 \pm 6.36 \\
(55-64)\end{array}$ & - & $\begin{array}{c}7.0 \pm 2.83 \\
(5-9)\end{array}$ & 2 \\
\hline me & Ecuador & Bolívar & 258 & 74 & 151 & - & 53 & - & 7 & 1 \\
\hline me & Ecuador & Loja & 227 & 69 & 158 & - & 58 & - & 7 & 1 \\
\hline
\end{tabular}




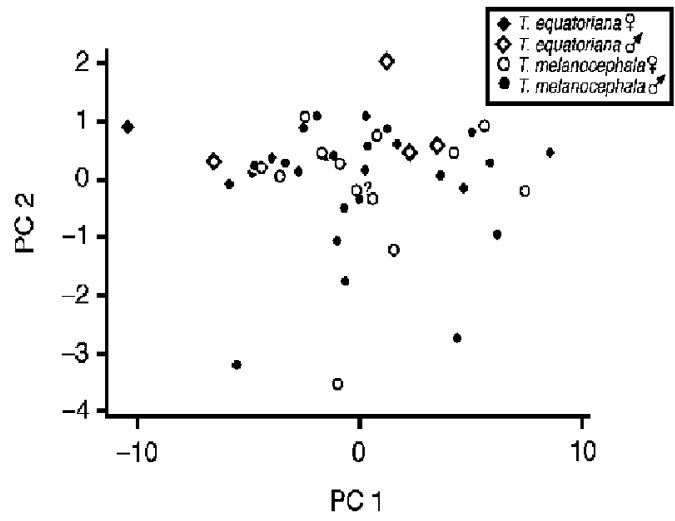

FIG. 2-Plot of specimen scores on first 2 axes of Principal Components Analysis of 22 linear measurements of Tantilla equatoriana and T. melanocephala. The question mark refers to a damaged specimen (MCZ 23871) of T. melanocephala of unknown sex.

The eigenvalue for PC3 was only 0.731 (3.5\% of the total variation) and is not examined in detail. Standard interpretation of eigenvectors (Manly, 1994) determined PC2 to reflect an axis of shape that contrasted RPTL, HedDep, RATW, and EyeNR measurements with those of SVL, NosDis, RATL, 1stVen, and MidBod. Although most of the variation in these axes shows no obvious pattern, it is clear from the location of $T$. equatoriana specimens on the plot (Fig. 2) that there is a large amount of variation in PC2, even at the same locality. No clear differences between the sexes of either species could be identified from the PCA.

Discussion-Wilson and Mena (1980) studied the color pattern and morphology of T. melanocephala in great detail, but did not recognize pattern type $\mathrm{C}$ individuals from southeastern Colombia, Venezuela, "British West Indies", Bolivia, Brazil, and Argentina as a distinct species, even though they lacked any stripe pattern on the dorsum and were separated from other conspecifics by the Andes. It is likely that this decision was made because of the extensive overlap in the numbers of ventral and subcaudal scales among South American populations of the species (Wilson and Mena, 1980:13). Because the 2 type specimens of $T$. equatoriana fell outside the known range of numbers of subcaudals for the T. melanocephala Group at that time, it is not surprising that Wil-
TABle 2-Principal Components Analysis elements of the unit eigenvectors for log-transformed data of PC1 and PC2 for specimens of Tantilla equatoriana and T. melanocephala. See text for explanation of variables.

\begin{tabular}{lcr}
\hline \hline Variable & PC1 & \multicolumn{1}{c}{ PC2 } \\
\hline SVL & -0.198 & -0.216 \\
HedDep & -0.226 & 0.207 \\
Ant1st & -0.237 & 0.019 \\
NosDis & -0.183 & -0.259 \\
RParL & -0.236 & 0.013 \\
RParW & -0.242 & 0.056 \\
FroL & -0.240 & -0.048 \\
FroW & -0.229 & -0.053 \\
RATL & -0.205 & -0.273 \\
RATW & -0.222 & 0.127 \\
RPTL & -0.115 & 0.725 \\
RPTW & -0.193 & 0.364 \\
RSupL & -0.222 & -0.080 \\
RSupW & -0.237 & -0.020 \\
1stVen & -0.191 & -0.179 \\
Inter & -0.234 & 0.006 \\
HW & -0.236 & 0.007 \\
Midbod & -0.227 & -0.155 \\
Vent & -0.228 & -0.094 \\
EyeNR & -0.234 & 0.114 \\
EyeDR & -0.207 & 0.017 \\
Eigenvalue & 15.581 & 1.147 \\
Proportion & 0.742 & 0.055 \\
Cumulative & 0.742 & 0.797 \\
\hline
\end{tabular}

son and Mena (1980) recognized this variation as diagnostic of a new species.

The collection localities of T. equatoriana are in an area of lowland tropical rainforest in northwestern Ecuador and are not geographically isolated from other proximate lowland areas (west of the Andes) where T. melanocephala has been collected (Dixon, 1979; Lynch, 1979). Moreover, specimens of T. equatoriana and $T$. melanocephala have been collected in the same vicinity at Santo Domingo de los Colorados, Pichincha Province, Ecuador (Fig. 3). Because these putative taxa seem to be sympatric, we agree that an operational definition of these species should include fixed diagnostic characters to delimit them (Wiens and Servedio, 2000). This contention is valid under the evolutionary species concept (sensu Wiley, 1978), as well as other species concepts (i.e., biological, phylogenetic, and cohesion) that designate a species as a lineage unified by sexual reproduction or gene flow among its inclusive parts 


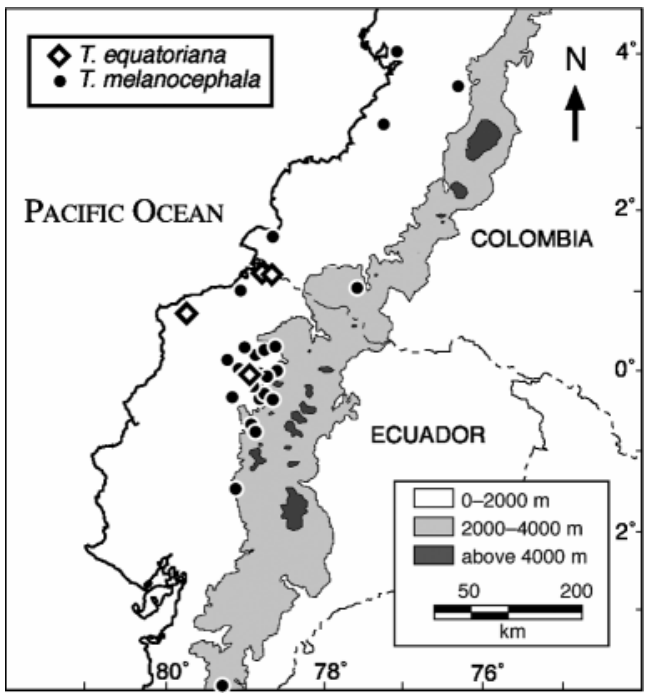

FIG. 3-Map of western Ecuador and southwestern Colombia showing collection localities for Tantilla equatoriana and T. melanocephala.

(Wiens and Servedio, 2000). The geographic overlap of different pattern types in populations of polymorphic species does not support the concept of independent lineages meriting species recognition, especially when one considers the overlap of scutellation characters demonstrated herein.

Our observations indicated that variation in every color pattern and scutellation character (except the preocular spot) employed by Wilson and Mena (1980) to distinguish T. equatoriana from T. melanocephala overlapped to varying degrees. Because the only non-overlapping character, the pale preocular spot, varied intraspecifically among the individuals identified as T. equatoriana, we argue that it cannot be used to diagnose the species unequivocally. Given the substantial variation in pigmentation of the head of $T$. equatoriana and $T$. melanocephala specimens (Fig. 1), we argue that this character is not appropriate to distinguish either taxon. Moreover, this character is not defined adequately in the original description of $T$. equatoriana as explained above. Concomitantly, the results of the PCA clearly showed that the specimens of T. equatoriana did not form a cluster distinct from those of T. melanocephala (Fig. 2), but rather encompassed most of the variation shown in T. melanocephala. Given that both putative taxa occur sympatrically and, in the ab- sence of invariant, unique, or non-overlapping characters to distinguish T. equatoriana from its congeners, we propose that T. equatoriana Wilson and Mena, 1980, be regarded as a junior subjective synonym (International Commission on Zoological Nomenclature, 1999) of T. melanocephala (Linnaeus, 1758).

We would like to thank R. Anderson and N. Slade for discussions of multivariate statistics and for useful comments on the manuscript. The manuscript also was greatly improved by the suggestions of $\mathrm{J}$. Dixon, W. E. Duellman, E. Liner, J. R. Mendelson III, J. Pramuk, A. Pugener, C. Sheil, O. Torres, L. Trueb, and L. D. Wilson. We are grateful to J. Simmons (KU), J. Campbell, R. Ackley (UTA), L. Ford $(\mathrm{AMNH})$, A. Resetar, H. Voris (FMNH), G. Zug, R. McDiarmid, R. Reynolds, R. Wilson, W. R. Heyer (USNM), J. Rosado, J. Hanken (MCZ), D. Wake (MVZ), K. Beaman (LACM), L. Coloma, S. Ron (QCAZ), V. Mahnert, J. Mariaux, A. Merguin (MHNG), and respective museum staff for the loan of specimens. T. Holmes provided resources and J. M. Guayasamin provided an excellent base map. This paper is dedicated to the memory of our (AA \& JLC) esteemed colleague and travel companion, Ted Parker, who collected one of the T. equatoriana specimens in 1991.

\section{Literature Cited}

BURBRINK, F. T. 2001. Systematics of the eastern ratsnake complex (Elaphe obsoleta). Herpetological Monographs 2001:1-53.

Cánseco-Marquez, L., J. R. Mendelson, III, and G. GutiÉRrez-MaYÉn. 2002. A new species of large Tantilla (Squamata: Colubridae) from the Sierra Madre Oriental of Puebla, Mexico. Herpetologica 58:492-497.

Dixon, J. R. 1979. Origin and distribution of reptiles in lowland tropical rainforests of South America. In: Duellman, W. E., editor. The South American herpetofauna: its origin, evolution, and dispersal. Museum of Natural History, University of Kansas, Monograph 7. Pp. 217-240.

Dowling, H. G. 1951. A proposed standard system of counting ventrals in snakes. British Journal of Herpetology 1:97-99.

INTERNATIONAL COMMISSION ON ZOOLOGICAL NOMENCLATURE. 1999. International code of zoological nomenclature. International Trust for Zoological Nomenclature, London, United Kingdom.

Leviton, A. E., R. H. Gibbs, JR., E. HeAl, And C. E. DAwSON. 1985. Standards in herpetology and ichthyology: part I. Standard symbolic codes for institutional resource collections in herpetology and ichthyology. Copeia 1985:802-832.

Linnaeus, C. 1758. Systema naturae per regna tria 
naturae, secundum classes, ordines, genera, species cum characteribus, differentiis, synonymis, locis. Tenth edition, volume 1. L. Salvius, Stockholm, Sweden.

LyNCH, J. D. 1979. The amphibians of the lowland tropical forests. In: Duellman, W. E., editor. The South American herpetofauna: its origin, evolution, and dispersal. Museum of Natural History, University of Kansas, Monograph 7. Pp. 189-215.

Manly, B. F. J. 1994. Multivariate statistical methods: a primer. Chapman \& Hall, London, United Kingdom.

Parker, T. A., III, AND J. L. CARr, editors. 1992. Status of forest remnants in the Cordillera de la Costa and adjacent areas of southwestern Ecuador. Rapid Assessment Program Working Papers 2, Conservation International.

SAVAGE, J. M. 2002. The amphibians and reptiles of Costa Rica: a herpetofauna between two continents, between two seas. University of Chicago Press, Chicago, Illinois.

SAwaya, R. J., AND I. SAzima. 2003. A new species of Tantilla (Serpentes: Colubridae) from southeastern Brazil. Herpetologica 59:119-126.

STAFFORD, P. J. 2004. A new species of Tantilla (Serpentes; Colubridae) of the Taeniata Group from southern Belize. Journal of Herpetology 38:4352.

THORPE, R. S. 1985. Character number and the multivariate analysis of simple patterns of geographic variation: categorical or "stepped clinal" variation. Systematic Zoology 34:127-139.

Wiens, J. J., AND M. R. SERVEdio. 2000. Species delimitation in systematics: inferring diagnostic differences between species. Proceedings of the Royal Society, London, B 267:631-636.
Wiley, E. O. 1978. The evolutionary species concept reconsidered. Systematic Zoology 27:17-26.

Wilson, L. D. 1988. Tantilla equatoriana. Catalogue of American Amphibians and Reptiles 453:1.

Wilson, L. D. 1999. Checklist and key to the species of the genus Tantilla (Serpentes: Colubridae), with some comments on distribution. Smithsonian Herpetological Information Service 122:136.

Wilson, L. D., And C. E. MenA. 1980. Systematics of the melanocephala group of the colubrid snake genus Tantilla. San Diego Society of Natural History, Memoirs 11:1-58.

Submitted 30 September 2003. Accepted 11 January 2004. Associate Editor was Geoffrey C. Carpenter.

APPENDIX I-Specimens Examined-Museum numbers follow names of species examined, number of specimens in parentheses, and locality information.

Tantilla equatoriana (5): Ecuador, Esmeraldas, USNM 198530 (holotype), USNM 198429 (paratype); Ecuador, Esmeraldas, EPN 2552, 8654; Ecuador, Pichincha, USNM 198728.

Tantilla melanocephala (42): Colombia, Chocó, LACM 72749; Colombia, Nariño, AMNH 20400, FMNH 54884; Colombia, Valle del Cauca, AMNH 4480, MVZ 68711, USNM 267258; Ecuador, Bolívar, AMNH 35945; Ecuador, Cotopaxi, QCAZ 206 , USNM 198730; Ecuador, Esmeraldas, QCAZ 2235; Ecuador, Loja, USNM 198736; Ecuador, Pichincha, KU 202954, MCZ 147302, 164419, 164503, 166542 , QCAZ 393, 1283, 1569, 1651, USNM 198723-27, 198729, 198731-33, 285502, 287934-38; Panama, Darién, FMNH 170141; Panama, Panamá, FMNH 83554, MCZ 23870-72, 26764, USNM 140702. 